\title{
Geometric Themes in Villae of the Conventus Pacensis Conventus Pacensis Villaları'ndaki Geometrik Motifler
}

Maria de Jesus DURAN KREMER*

(Received 18 December 2016, accepted after revision 04 July 2017)

\begin{abstract}
The project of drawing up an inventory of Roman mosaics in the territory of present-day Portugal requires, in the first stage, a methodical consultation of as many existing sources of information as possible, both of the current and of the past centuries. In doing so, trends in the compositional grammar and in the iconographic discourse chosen will gradually be outlined, eventually allowing the individualization of local, regional or even itinerant workshops.

In the process of consulting the records of Roman mosaics in Portuguese territory of Lusitania we can identify the existence of geometric mosaics in Roman villae of Alentejo, less known but not less interesting as regards the repertoire of their floors. From some of them - disappeared in the years following their discovery - there is nothing left but the reports of the archaeological campaigns then carried out and one or another photograph or drawing included in them.
\end{abstract}

Largely in very poor state of conservation, the still existing fragments are, today, testimony of a very own decorative syntax.

Keywords: Mosaics, inventory, geometric motifs, iconography, mosaic workshop.

Öz

Günümüzde Portekiz sınırları içerisinde yer alan mozaiklerin envanterlenmesi projesi, ilk olarak mümkün olan en geniş ölçüde hem günümüz hem de geçmiş literatürden metodik destek almayı gerektirmektedir. Bunu yaparken, kompozisyon gramerinde ve seçilen ikonografik yapıdaki eğilimlerle ilgili aşamalı bir genel çerçeve çizilecek ve bunun sonucunda da yerel, bölgesel veya hatta gezici atölye çalışmalarının ayırt edilebilmesi mümkïn olacaktır.

Portekiz'in Lusitania Bölgesi'nde yer alan Roma mozaiklerinin kayıtlarına bakma sürecinde Alentejo Roma villaları'nda bulunan geometrik desenli mozaiklerin tanımlanması mümkün olabilmiştir. Bu taban mozaikleri az bilinmekle birlikte repertuvarları açısından oldukça dikkat çekicidirler. Bu mozaiklerin bazılarından bulunmalarını takip eden yıllar içerisinde kaybolan kısımlar olmuş, bazılarından ise geriye, arkeolojik çalışma raporlarında yer alan fotoğrafları ve çizimleri dışında bir şey kalmamıştır.

Büyük ölçüde kötü korunmuş bu mozaiklerin, günümüze ulaşan kısımları kendilerine özgü dekoratif üslubu ifade edebilmektedir.

Anahtar Kelimeler: Mozaikler, envanter, geometrik motifler, ikonografi, mozaik atölyesi.

The elaboration of an updated inventory of Roman mosaics in Portuguese territory was, right from the start of the Portuguese-Turkish project "Roman mosaics with geometric motifs to the West and the East of the Mediterranean. A comparative study of the reciprocal influence on the evolution of Roman geometric patterned mosaics in Portugal

\footnotetext{
* Maria de Jesus Duran Kremer, PhD's degree in Classical Archaeology and Portuguese Philology, PhD Researcher at the Institute of Art History of the Faculty of Social Sciences and Humanities / Universidade Nova de Lisboa - Portugal. PI and coordinator of the international project RoGeMoPorTur.E-mail: mjesuskremer@hotmail.com
} 
and Turkey "(RoGeMoPorTur $)^{1}$, one of the fundamental objectives of the Portuguese team.

Conscious of the difficulties that the non-existence of such an inventory implies for the study of mosaics in general and, more specifically, for the study of Roman mosaics with geometric motifs, it was decided to use the process of bibliographical survey of the Roman mosaics in Portuguese territory and, doing so, contribute to bridge this gap. Parallel to the database common to both countries, an inventory of the Roman Mosaics of Portugal is being prepared, following, with some adaptations, the structure chosen for the Mosaic Corpus of Spain. In it, in mosaic description forms that follow, as far as possible, the informative structure chosen for the Corpus of the Mosaics of Portugal, will briefly be gathered all the information obtained through the analysis of the existing and accessible bibliography ${ }^{2}$.

In a first stage and in the context of the current process of debugging the Bibliography on existing or missing mosaics, we limited ourselves to the Conventus Pacensis, more precisely to the present districts of Portalegre, Évora and Beja. In fact, the number of entries in this area of the conventus pacensis is so high that we started the survey by analysing the documentation available at the Regional Directorate of Culture of Alentejo, whom we sincerely thank for the support given in this task, allowing access to the folders, accompanying with a smile all our doubts and questions ${ }^{3}$.

\section{Why conventus pacensis?}

"In Portugal, the exploitation of landowners seems to be confined to the Alentejo; in fact, it is the only region in the country which, due to its pedological, hydrological and demographic characteristics, lent itself to this type of exploitation". With these words, Professor Jorge de Alarcão opens chapter V of the "Roman Dominion in Portugal", to this very day the reference work for those who dedicate themselves to the study of the Roman age in our territory.

The villae were originally intended to ensure the existence of the senatorial nobility, who applied their fortune exclusively to large estates. For the production of agricultural products - olive oil, wine and cereals, there were multiple buildings: in addition to the facilities for the cultivation of land - pars rustica and pars fructuaria - a whole series of divisions were built as a mansion for the daily life of the family of the owner of the land and for reception and representation to the outside. Among others, gardens, water games, peristyle, triclinia, nimphea, embellished the manor house and witnessed - with the visitor - the prosperity and importance of its inhabitants. Especially social contacts between landowners were well cared for: to this effect, the private sphere of the villae was also an expression of a spirit of competition among the members of the Roman elite. The villae owners often owned several properties in different climatic regions and zones, which they visited according to the seasons. In doing so, they reduced the danger of bad harvests on the one hand, and allowed themselves to enjoy different landscapes and facets of Nature on the other hand.

1 Multi-annual Archaeological Research Project approved by the General Directorate of Cultural Heritage of Portugal (DGPC).

2 The last inventories of Roman mosaics in Portugal were elaborated by Alarcão (1988), by Duran Kremer (1999) and by Abraços (2005).) For previous bibliography see Abraços 2005: 183-200.

3 Our special thanks go to all the staff of the DRCAlentejo in the person of the Regional Director Ana Paula Amendoeira and especially to Gabriela Cabeça, who has always accompanied me, and to the archaeologists and colleagues António Carlos Silva and Rafael Alfenim, whose support was central to this study. 
Among the still existing testimonies of this important aspect of Roman everyday life, mosaics are an inexhaustible source of information on this aspect of the Roman culture. The architecture of the villa, the number and distribution of the different rooms, the iconographic program chosen for each of them according to their function in the representative universe of the landlord, the decorative syntax of each of them - are just some of the aspects that allow us to define the socio-economic and cultural profile of the villa owner with some certainty at any given time.

Moreover, this analysis often makes it possible to identify a possible mosaic workshop, acting at a regional level - or, on the contrary, the passing by of traveling workshops, so common at a time when the movement of people and goods was already a reality. Since the ground in Alentejo is primarily in the hand of landowners, it concentrates in its territory a large number of roman villae, more or less well known mainly for their architecture, sculpture and / or in large part figurative mosaics. This is the case of Torre da Palma, Santa Vitória do Ameixial, Casa da Medusa, Pisões, Vila das Longas, etc.

In many other cases, however, apart from a quotation here and there in the mostly local press, the villae of this region have fallen into oblivion, partly (or in some cases totally) destroyed. The only remaining information comes down to a few newspaper news, excavation reports and the photographs taken at the time. And that regardless of the fact, that many of these villae, due to the findings and the architectural and decorative planning of their rooms and pavements, could have been a determining factor in the study of the different forms of settlement and socio-cultural framework of the region.

At the time, beautiful mosaic floors were found. Unfortunately, however, while the most "beautiful" or "significant", reproducing figurative scenes, were very carefully taken care of and outlasted in a good state of preservation, mosaics with geometric pattern were only very rarely given the same attention. On the contrary: not being front page news, the data we have today on many of them are very limited. A factor that seriously hinders the comparative study of mosaics with geometric motifs: Since it is not possible, in most cases, to reconstruct the iconographic program of the building or even the room in which the pavement was found, we are limited to analysing only a few aspects of the individualized system of decoration chosen for some rooms of the villae of the conventus pacensis. Compositional grammar, decorative syntax, polychromy, combination and execution of motifs are elements that, although they have come down to us only in fragments, are nevertheless indicative of the iconographic choice of the owner and of the hands that executed it.

As an example, we can briefly relate the history of an emblematic villa, which we had the opportunity to visit in the earlies 70's, shortly after its discovery.

\section{Roman villa of D. Pedro (Herdade de Fonte de Frades, Baleizão) ${ }^{4}$ (Figure 1)}

In the course of the agricultural work 1971 the existence of a vast area with archeological remains (Roman walls, fragments of pottery and mosaic) on the surface in a place called D. Pedro, at Herdade de Fonte de Frades (Beja) was noticed and the authorities ${ }^{5}$ were immediately informed of the probable existence

4 See Abraços 2005: $\mathrm{N}^{\circ} \mathrm{s} 171$ e 175 -01 a 05.

5 At the time, the National Board of Education 


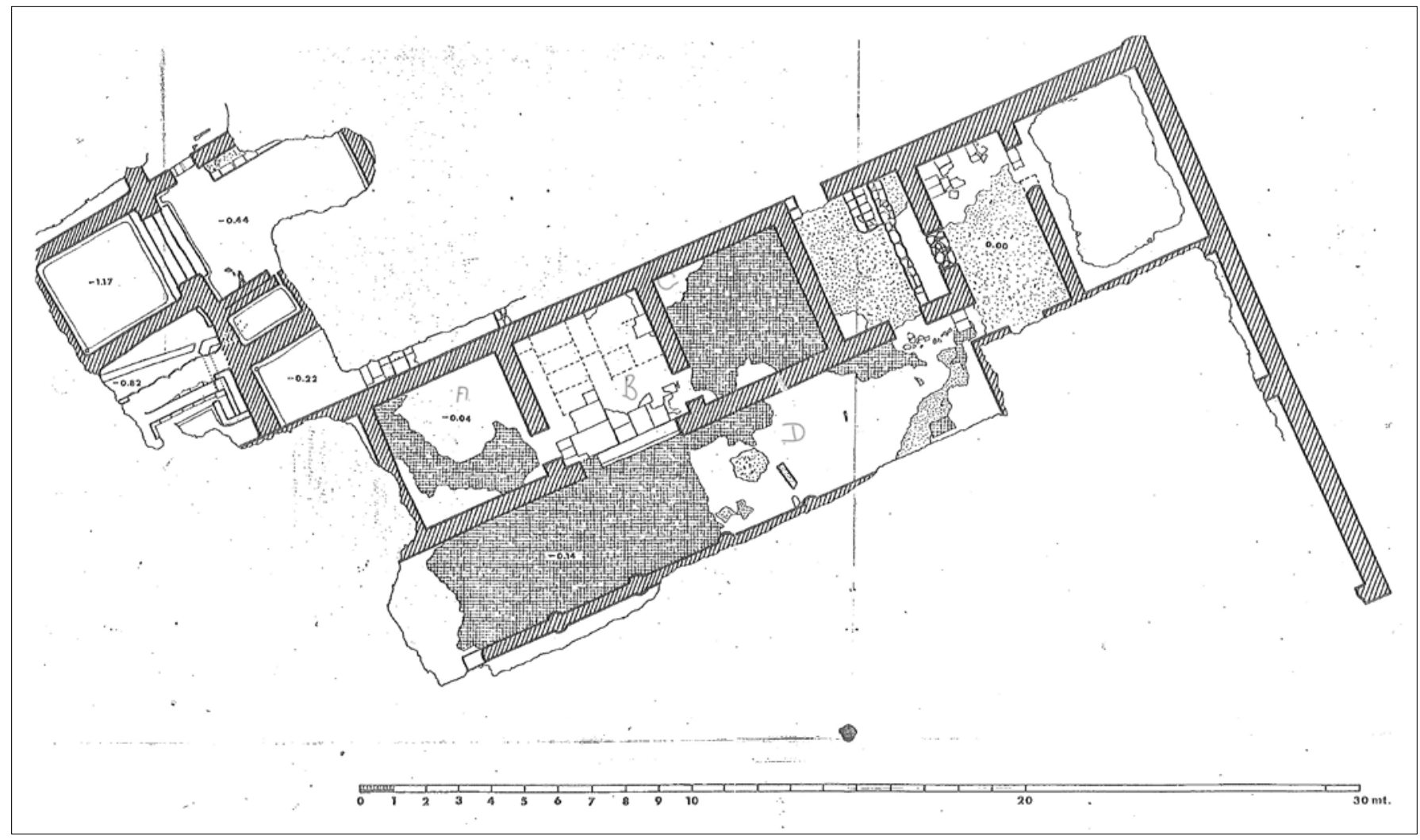

of an important Roman station in that place. Unfortunately, as has happened with other archaeological sites in the past, the agricultural exploitation of the fields did not stop and went on destroying the existing archaeological heritage, day

Figure 1 Herdade de Fonte de Frades, Plan. CDRCAlentejo after day ${ }^{6}$.

Faced with this situation, an excavation campaign was carried out in $1972^{7}$, in the course of which six rooms, that flanked a wing of what is supposed to be the peristyle of the villa, were discovered ${ }^{8}$, as well as other structures that were only partially "cleaned".

Among the materials found near the considered area were "a large marble ram" and a "small bronze statuette", a stone column base, two Roman coins from the $4^{\text {th }}$ century, circular column brick spindles of different diameters (Figs. 2 - 4) etc.

According to the report of the excavation campaign of 1972, twelve mosaic fragments were found, with an average surface of $30 \times 25 \mathrm{~cm}$, mostly decorated with

6 We will not dwell in detail on the various stages of destruction of this "villa", which is being currently the subject of a detailed study to be published in due course. We refer here only the most important moments in order to situate the mosaics found in time and space.

7 The Excavation Campaign was directed by the archaeologists Manuel Maria da Fonseca Andrade Maia and Maria Adelaide de Figueiredo Garcia Pereira. We thank the DRCA in the person of its Regional Director Ana Paula Amendoeira for the authorization to consult and use the information, plans and photographs existing in that DR, both for this archaeological station and for the other mosaics to be dealt with in this paper.

8 Since as far as we know, the excavations of this area have not proceeded, it is necessary to consider also the hypothesis of having found a villa ordered along a corridor, as happens in the roman villa of Pisões, Beja.

9 Offered by the owner of the land to the MNA in the person of D. Fernando de Almeida, when he visited the villa (letter from R.M. Rosado Fernandes to the President of the National Board of Education of May 10, 1972). 
Figure 2

Herdade de Fonte de Frades CCMJ Duran Kremer

Figure 3

Herdade de Fonte de Frades CMJ Duran Kremer

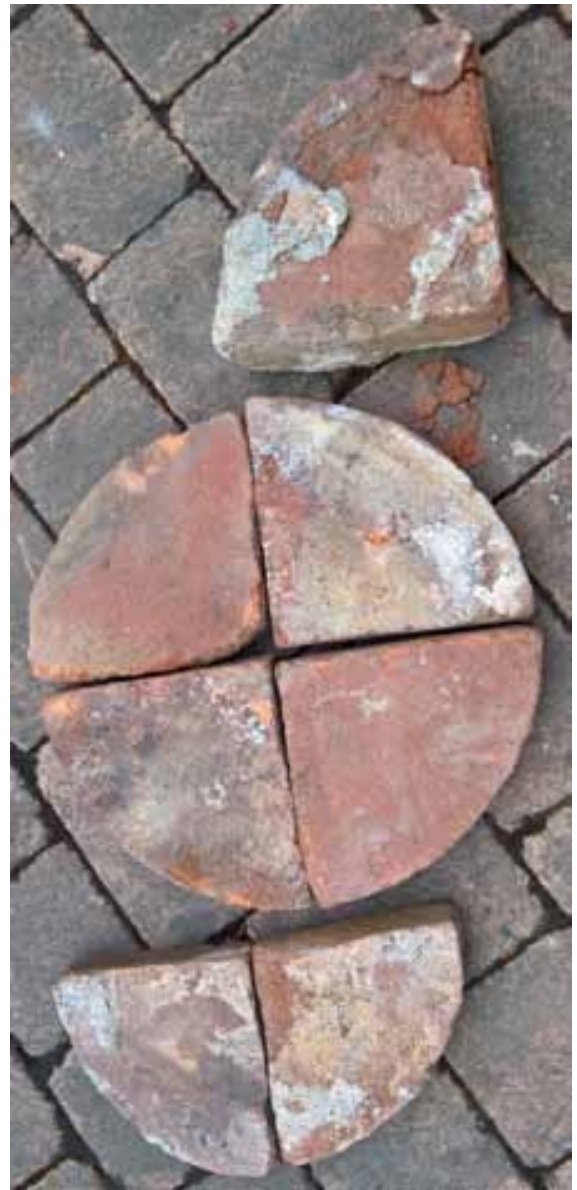

Figure 4

Herdade de Fonte de Frades.

CCMJ Duran Kremer
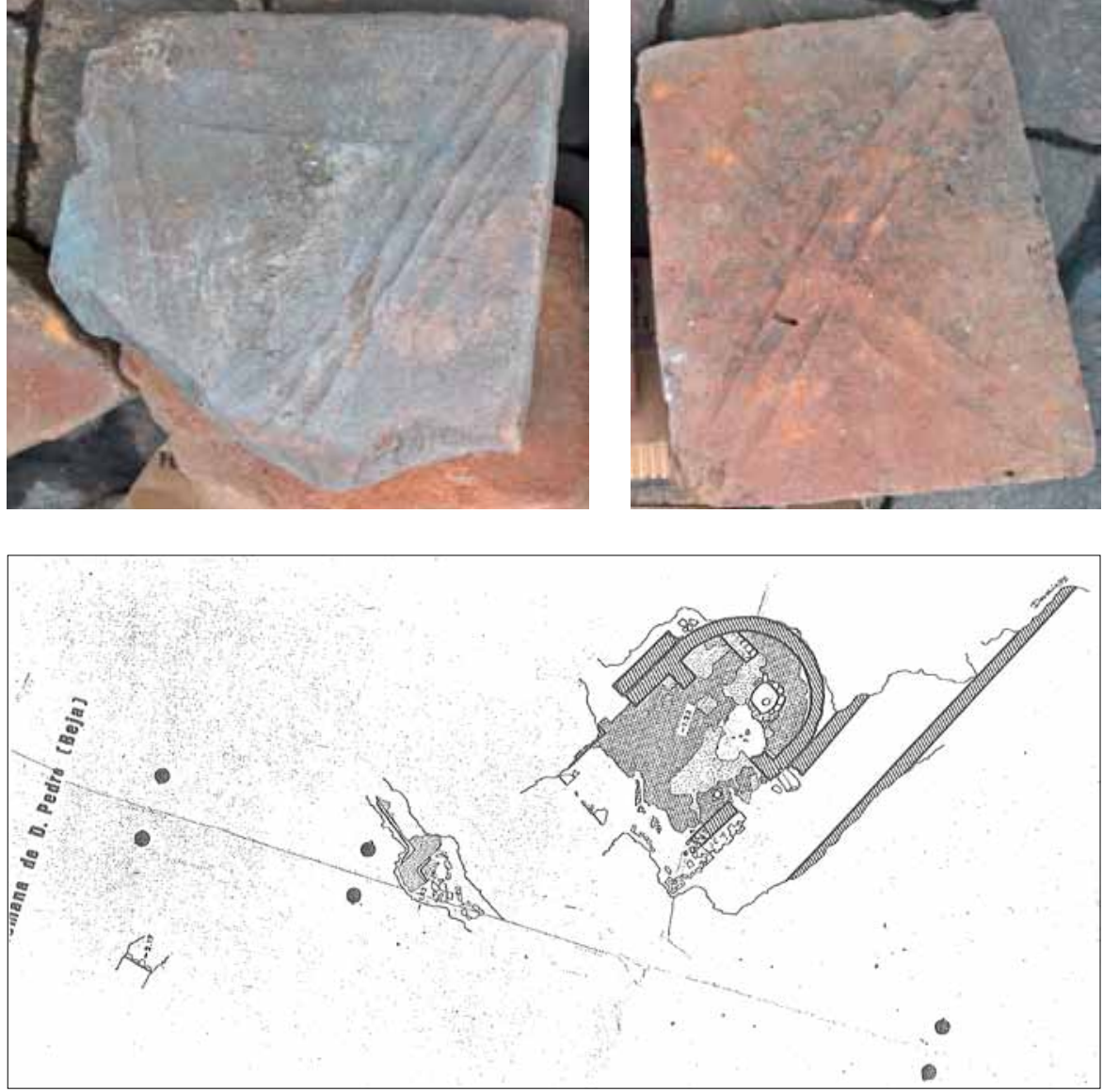

Figure 5

Villa romana de D. Pedro, Plan. CDRCAlentejo

black and white geometric motifs, and a polychrome one, also decorated with geometric motifs ${ }^{10}$.

After this first excavation, the archaeological site fell into oblivion, and the existing structures - among them the mosaics - were completely destroyed ${ }^{11}$.

Years later, in 1983, farming work in what was then the UCP - Unidade Cooperativa de Produção - "Terra de Catarina" - uncovered structures probably belonging to this villa ${ }^{12}$ (Fig. 5). An emergency intervention was immediately carried out to assess the value of the findings, and the polychrome floor discovered at the time was described as follows:

"The partially exposed pavement $(2 \times 1,5 \mathrm{~m})$ is made of tesserae and has two distinct parts: on the sides, the white marble and basalt tesserae form geometric patterns with floral motifs. And in the center the mosaic is polychrome with several motifs, of which two craters, ornamented with great swastikas stand out

10 A polychrome figurative mosaic representing dolphins was also found. The poor quality of the photograph at our disposal does not allow us to reproduce it here, but hopefully get a better photograph for the publication of the study of the villa, which is under way.

11 I had the opportunity of confirm this fact when, years later, I visited the Monte de D. Pedro and, together with the farm manager, went to the place where the ruins of the villa had existed.

12 When I visited the ruins in the 70's, the landowner referred to more existing structures at some distance from the villa and considered that they could be the roman baths. The partial transformation of large latifundia into UCPs, following the Agrarian Reform introduced by the Revolution of 1974, lead to a division of this area into different "farms", thus giving rise to this "unprecedented archaeological station". To be confirmed later in the scope of the ongoing study. 
(fot.). These motives are framed by simple guilloche, in brick and green marble tesserae, giving them a very bright shade. As for the construction, it is formed by two walls of stone and lime, culminating in a vault. The visible height is $1,30 \mathrm{~m}$ and the width $0,8 \mathrm{~m}$ In the same place there is an opus signinum pavement, fragmented in two parts. The specialists identified these architectural elements as belonging to the balnearium, more precisely the hypocaustum "13 (Fig. 6).

It was the year of 1983 .

Then, for various reasons, the ruins returned to oblivion. The mosaics, which had been uncovered, were destroyed: In 1989, it could be seen that the whole area had been puffed up and nothing remained from the mosaics or the walls except the reports of the excavation I had the opportunity to consult.

\section{Mosaics with geometric patterns}

Since it is impossible to analyse all the fragments of mosaic referred to in the 1972 report, we will limit ourselves to analysing only three floors decorated mainly with geometric patterns.

1. Bichrome mosaic - diamonds and four-pointed stars with square centre Octogonsystem IX (Salies 1974: 14 fig.49; Vargas Vázquez 2016: 259 fig. 29) (Fig. 7).

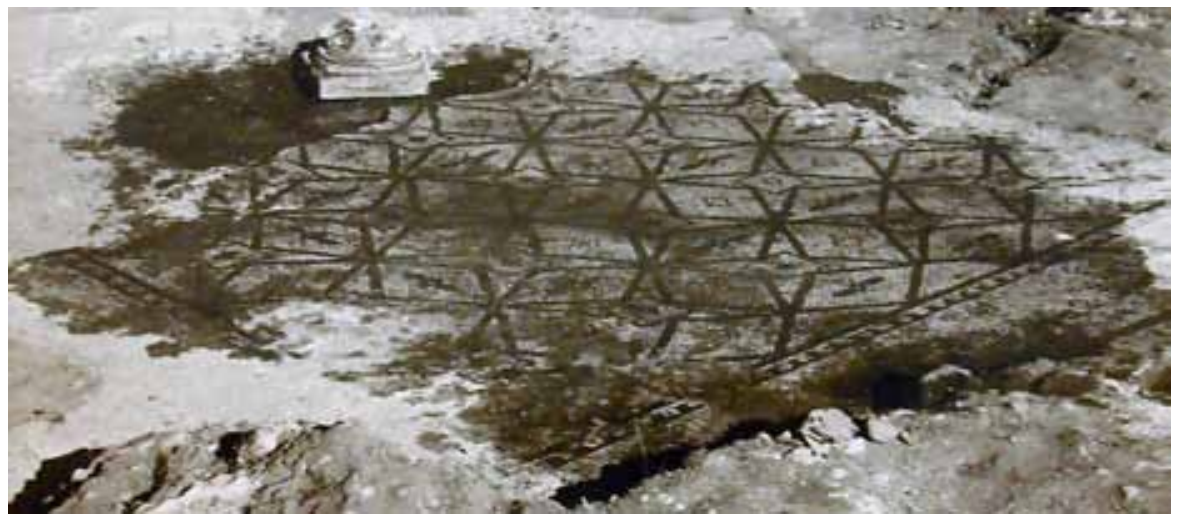

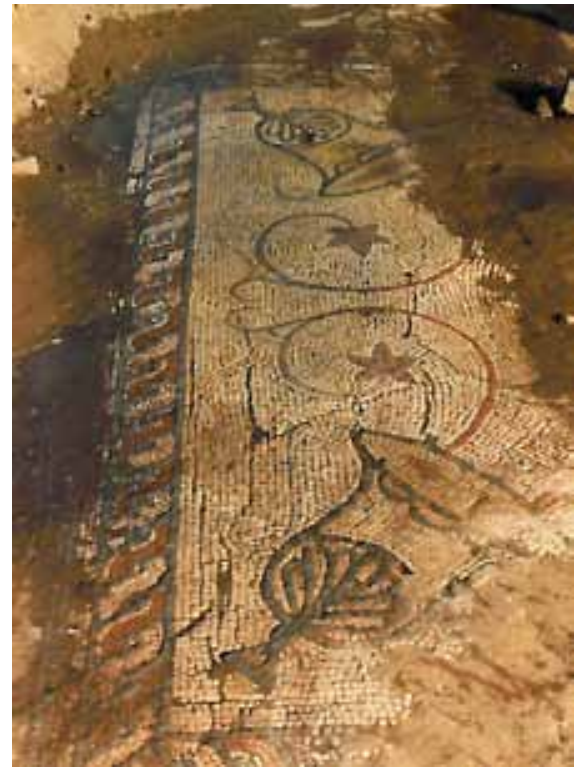

Figure 6

Villa romana de D. Pedro, Mosaic. (C) Câmara Municipal de Beja

A carpet-type mosaic, bichrome, in white and black tesserae, was part of a larger set of two rooms, both with mosaic pavements ${ }^{14}$.

The mosaic probably covered the entire floor of the room, and was delimited by a dentilled simple filet with dentils 3 tesserae wide (Décor I: pl. $3 \mathrm{~b}$ ) that framed the central composition. As far as we can tell, there was a broad band of white tesserae, surmounted by a line of (probably) three black tesserae and a band of white tesserae ${ }^{15}$.

The decorative syntax of the pavement is alternately repetitive: the diamonds formed by the four-pointed stars are filled with small floral elements or small

13 Municipal Bulletin (Boletim Municipal 1983: No 27, p. 5). Our greatest thanks to the Municipality of Beja in the persons of Dr. Tereza Revez and Adelaide Lopes for the support and transfer of photographs and reference material.

14 The plant at our disposal does not allow us to identify the location of these two mosaics: The second one was already very destroyed during the excavation campaign and it was not possible to identify its decoration.

15 The photograph at our disposal does not allow a more detailed analysis of the finishing of the composition.

Figure 7

Herdade de Fonte de Frades, Mosaic. CDRCAlentejo 
diamonds (in sketch or solids). The squares inscribed on the four stars are equally sketched or solid.

The use of two colours and of the geometric system of ornamentation as an element of the composition introduces movement and a "pseudo singleness" and perspective in the decoration of the mosaic. Probably having its origin in Africa, this scheme is used mainly in mosaics of late antiquity, having reached its peak in the $4^{\text {th }}$ century AD. They are almost always connected to a local mosaic workshop (Salies 1974: 14) and would have spread from the West to the eastern Mediterranean provinces (Salies 1974: 89) ${ }^{16}$.

\section{Bichrome mosaic - peltae (Décor I: pl. 222d).}

A black and white tessellated carpet-type surface mosaic covered a square room approximately of $3 \times 3 \mathrm{~m}$ (Plan, room A): According to the Excavation Campaign Report, this floor would show the same decoration as room C.

Still, according to the Report of the Excavation Campaign (1972), this room would open in the West side to another, with the same dimensions, whose pavement - although quite destroyed - still had a part of its covering of marble stone ${ }^{17}$ (Plan, room B).

To the West of this room a door led to room C, also with a mosaic floor, relatively well preserved (Plan, room C).

\section{Bi-chrome mosaic - peltce (Décor I: pl. 222 variant of d;} Vargas Vázquez 2016: 206) (Figure 8).

A black and white tessellated carpet-type surface mosaic covered a square room approximately $3 \mathrm{~m} \times 3 \mathrm{~m}$ (room C) and consisted of a uniformly patterned central carpet in running peltce pattern, delimited by a dentilled simple filet with dentils 3 tesserae wide (Décor I: pl. 3b) that framed the central composition. As far as we can see, there was a broad band of white tesserae, surmounted by a line of (probably) three black and a band of white tesserae.

Figure 8

Herdade de Fonte de Frades,

Mosaic room C.

CDRCAlentejo

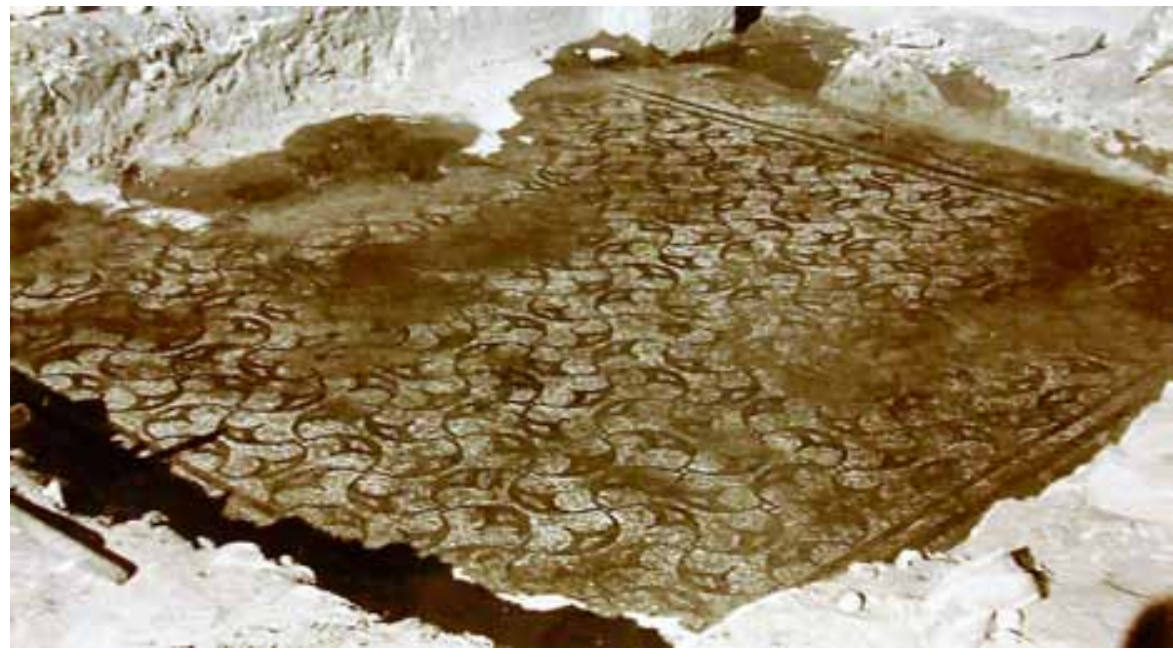

16 "In der spätantiken Mosaikproduktion ist der völlige Stilwandel in der syrischen Fußbodendekoration besonders auffallend ... Die im Westen seit langem bekannten Schemata werden übernommen - vor allem ...... die Oktogonschemata III, IV, VI und IX ... mit geometrischen Mustern dekoriert „.

17 Under the quadrant bricks that filled the hole left by the disappearance of the threshold was found a quarter of the $4^{\text {th }}$ century AC. 


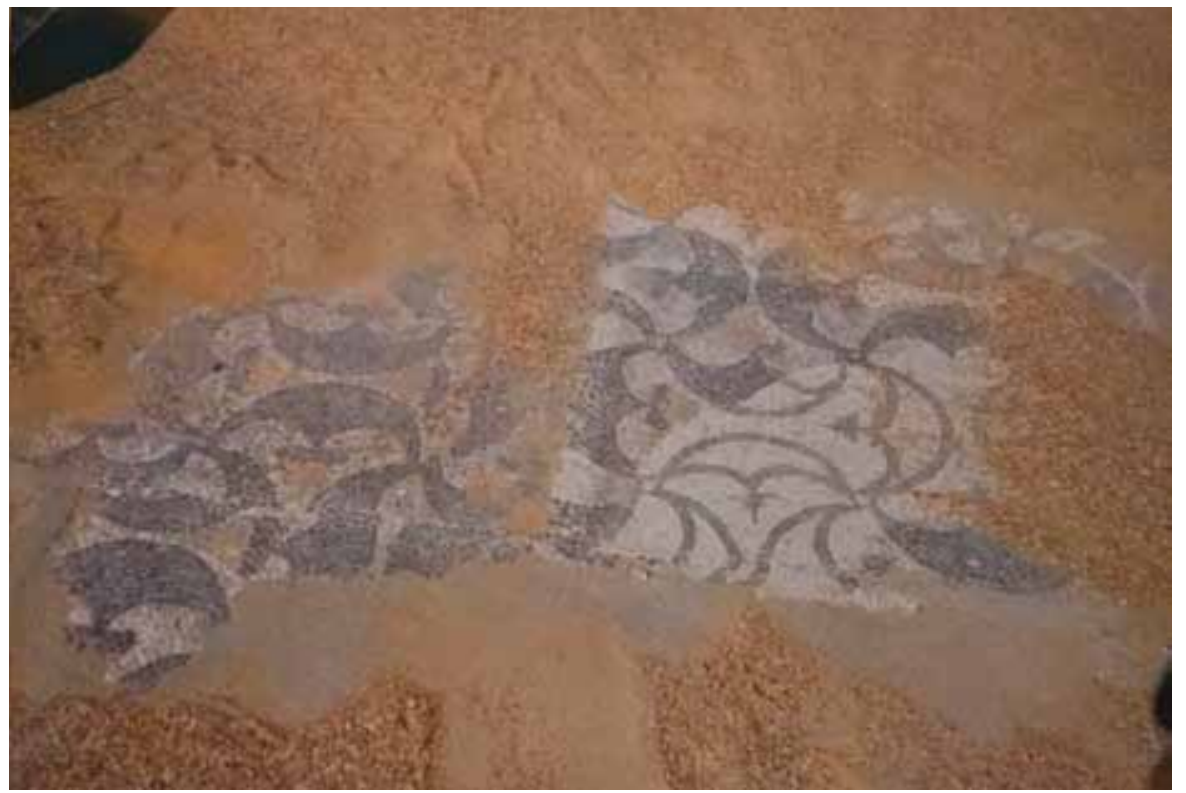

In this last strip, we can identify at least a cordiform leaves / ivy scroll (Nunes Correia 2005: 175) on the side of the entrance to the room.

The layout of these three rooms, perfectly symmetrical and with a single access (room B) open to what was identified as a wing of the peristyle of the villa is also found in another villa of the conventus pacensis - the Roman villa of Abicada (Duran Kremer 2007: 214-222) ${ }^{18}$.

Although the pelt, as a motif, is commonly used mainly in combination with the square, the circle and / or the Solomon's knot, both in surface compositions as well as in individual motifs, it was not frequently used as a single motif in mosaic floors and/ or surface compositions in the roman mosaics of today's Portuguese territory. However, it is also in the conventus pacensis that we find two other floors very close to those of room A and C:

- in the Casa da Medusa, Alter-do-Chão ${ }^{19}$, bichrome - white and black tesserae - in a composition in running pelta pattern covering what was probably a larger room, later divided by a later wall in two different, smaller rooms, one of which was then giving access to the peristyle.

- in the Roman villa of Pisões (Fig. 9), in the large corridor (23.60 m) that connects the "entrance" of the villa in the North to the large set of rooms already excavated in this archaeological station. Although in large parts destroyed and with numerous old and modern "repairs", it allows to identify a surface composition in running pelt pattern, originally in the colours white, black and yellow.

Another pavement with this motif as a surface composition but with a more complex chromatic and decorative syntax was found in the Monumental Complex of Santiago da Guarda, both in the small corridor and as pavement of cubiculae (Pereira 2011: 849-860).

18 Unfortunately the failure to continue the excavations and the destruction of the ruins does not make it possible to verify the existence of a possible symmetry in the layout of the rooms similar to that which occurs in at least in two sectors of the Roman villa of Abicada.

19 The mosaics of the Casa da Medusa (Alter do Chão) are an integral part of the doctoral thesis of the colleague (and member of the RoGeMoPorTur team) Jorge António. For this reason - and as we always do with material studied by colleagues - we do not publish photographs of this Roman station. 


\section{Polychrome mosaic (Figure 10)}

Identified in the plan by the letter $\mathrm{D}$, the area excavated and identified as pertaining to the peristyle had a length of $20 \mathrm{~m}$, covered with mosaic: from what can be inferred from the mosaics visible, at least this section of the peristyle $(8.20 \mathrm{~m})$ would have a panel-like decorative arrangement. As it is impossible to consult coloured photographs of high quality, we quote the archaeologists responsible for the excavation campaign: "the mosaic is polychrome and in it white, green and yellow tesserae are drawn with a rosacea, a kind of rose from the winds, a composition formed by lozenges (an eight-pointed star, note by the author) (Fig. 11), and another zone that we can call "carpet", consisting of a frame of stylized waves that fits a labyrinth, which constitutes the central figure. The whole mosaic has a longitudinal square formed by yellow bands (Maia Pereira 1972: 4).

Analysed more closely, the composition was probably a flooring arrangement in individual thematic panels, and unique so far in the chosen decorative syntax. Not because the chosen motifs are unusual, on the contrary: both the sexifolia ${ }^{20}$ and the eight-pointed star are usual motifs in Roman architectural decoration ${ }^{21}$, usually integrated in surface composition or, when taken individually, establishing a very complex dialogue between the shape and the image ${ }^{22}$. In the Roman villa of D. Pedro the motifs are used in their simplest expression, having probably resorted to the game of colours in opposition.

This hypothesis is confirmed by the second panel, still partially visible. Contrary to the identification given earlier, we believe that we are facing a meander (probably a bi-chrome one), which constitutes the central image of the panel, framed by a polychrome square (yellow and black bands?), then a simple wave pattern and a new frame that, although following the same decorative scheme of the previous panel, introduces a contrast of colours in its filling.

Figure 10

Herdade de Fonte de Frades, Mosaic room D.

CDRCAlentejo

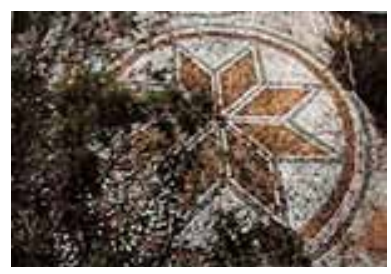

Figure 11

Herdade de Fonte de Frades, room $\mathrm{D}$, detail.

(C) Casa do Povo de Baleizão

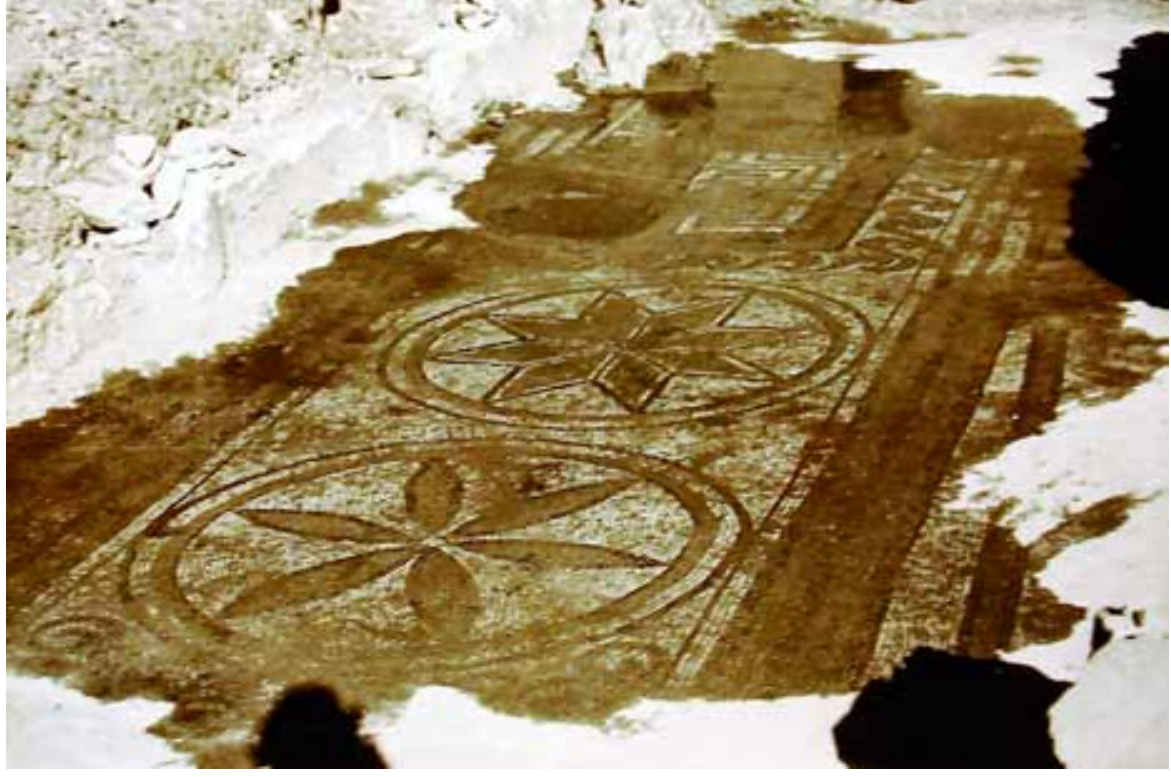

20 In the Roman villa of Pisões we find not the sexifolia but the quadrifolia inscribed in a circle in the composition of room 46 , where it stands out for its singleness when compared with the other patterns (Fig ....) and in room 1, where it is presented in a composition in black and white.

21 For the Architecture / Mosaic relationship see also Alves 2002.

22 This is the case, for example, of the central peristyle of the Casa dos Repuxos (Bairrão Oleiro 1992: Estampas 13-19). 
Apart from all the uncertainties associated with the impossibility of being able to personally analyse the pavements in detail, the elements at our disposal allow us to conclude that we would most probably be facing a large Roman villa with a very precise and significant decorative syntax. It is interesting to note that the excavated sector, near the peristyle, showed exclusively pavements decorated with geometric motifs, which, in their apparent simplicity, introduced movement - through the theme chosen - and harmony - through the symmetrical repetition of the motif: Rooms A and C. Or resorted to simple patterns - such as geometric themes inscribed in circles without any additional decoration - immediately followed by a "heavy" pattern in its message, as is the case of the meander in a colour contrast.

At the present stage of our work it is certainly premature to advance with interpretations of the "taste" of the landlords in this region of Lusitania in the fourth century $^{23}$. There may have been a preference for bi-chrome compositions - or for a minimalist polychromy - and for geometric patterns, a preference that we had already been able to verify in the Roman villa of Pisões ${ }^{24}$, but also found in several other villae of this zone of the conventus and that allows to identify certain tendencies, if not the hands of workers.

The treatment given to the meander on a floor of Santa Vitória do Ameixial and Monte das Argamassas illustrates this phenomenon well.

\section{The Roman villa of Monte das Argamassas}

Located in the district of Portalegre, in a flat area well served by natural watercourses, the Roman villa of Monte das Argamassas (now: villa da Herdade das Argamassas) is located on private property. Some archaeological interventions have taken place, all of them under the responsibility of the owners of the farm ${ }^{25}$.

During these interventions, and although it was possible to verify the existence of several mosaic floors, their state of destruction was such that, in most cases, it was decided not to continue the work (Brazuna 2011: 239). However, some of the existing fragments allow a comparative analysis of certain motifs. This is the case with the meander of room 6 (Brazuna 2011: 230) (Fig. 12).

The degree of conservation of the pavement does not allow identifying the decorative order in its entirety. It is true that we are probably dealing with a composition in surface, structured in large tangent squares with different inscribed motifs. At least three of these squares were filled by a linear, polychrome, dentate swastika-meander. The composition as a whole was framed by a bar of three rows of white tesserae, followed by a guilloche, a second bar of three rows of white tesserae that followed a bi-chrome row of intersecting and tangent semicircles, forming ogives and scales, the colours counter changed, the ogives concentrically striped (Décor I: pl. 49b). The outer cap was then formed by a sequence of black line (two tesserae), white band (8 tesserae) and again a black line (two

23 We limit ourselves here to the dates advanced by previous researchers. However, in the scope of the RoGeMoPorTur project, we hope to have access to more written sources and photographs that will allow them to move forward in this field.

24 A bichrome that does not mean a limitation in the muscled repertoire, on the contrary, points to a careful treatment of the geometric scheme used as decoration. The mosaic later discovered in the eighties and considered to belong to the baths of the village testify to the expertise of the workers who executed the mosaic floors.

25 Plan: Brazuna 2011: 235. 
Figure 12

Monte das Argamassas, Mosaic. (CDRCAlentejo

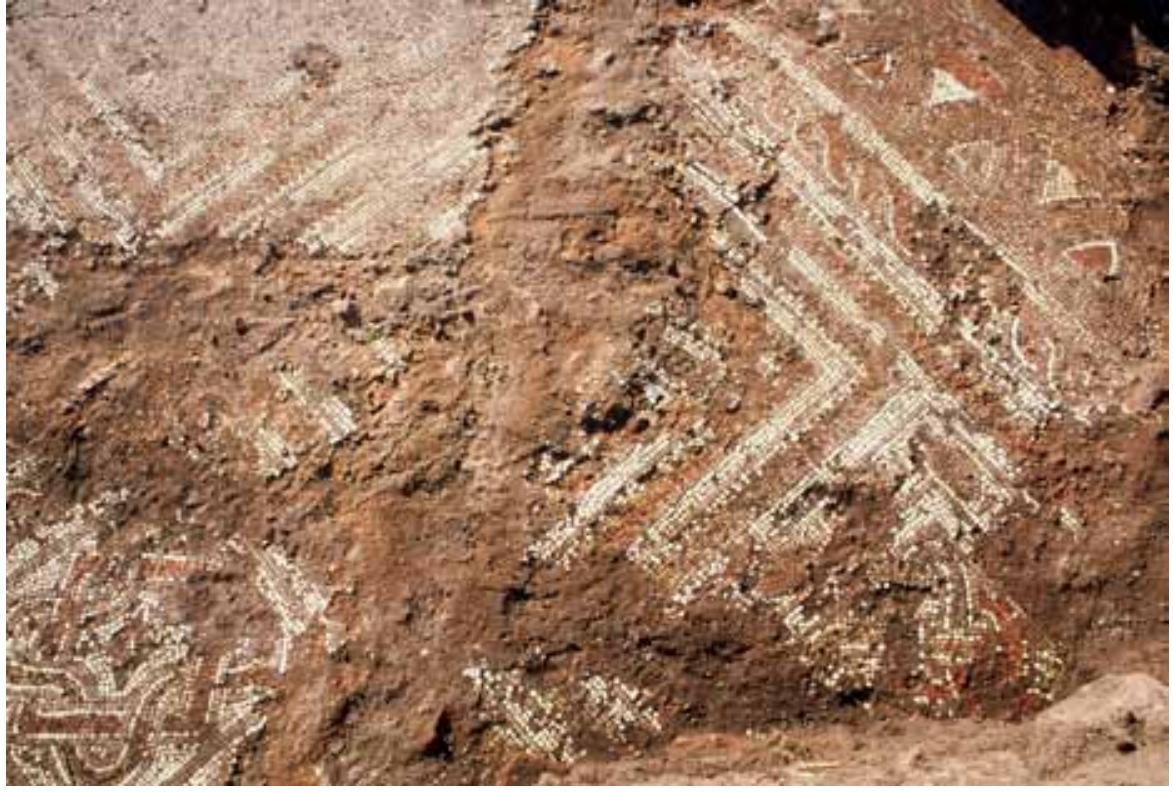

tesserae). It would probably follow a band of yellow tesserae, constituting the end of the pavement up to the wall ${ }^{26}$.

The decorative syntax of this sector of the pavement is relatively complex, bringing together exclusively geometric individualized motifs, with no apparent interconnection between them ${ }^{27}$. Of a pronounced polychrome still resorting to only four colours (white, black, red and yellow), witnesses of an iconographic program based on the variety of motifs and polychromy as elements of introduction of movement in the composition.

The bristled swastika-meander is undoubtedly one of these basic elements.

Although this motif has been used with a certain frequency on Roman pavements in the territory of Lusitania ${ }^{28}$, the use of at least three colours (yellow, red and black) for the construction of the same and the introduction of the "jagged" element in that same line does not have - as far as we know - until now a parallel in Portuguese territory ${ }^{29}$ : the only parallel of which we have knowledge of, is in the Municipality of Estremoz, Parish of Santa Vitória do Ameixial.

\section{The Roman villa of Santa Vitória do Ameixial}

Despite the knowledge of the existence of ancient ruins since the 18th century, when Father Luis Cardoso referred to them in his Geographical Dictionary as "land of moors", it was not until the beginning of the $20^{\text {th }}$ century that this villa took the front page of the newspapers with the discovery of the so-called Ulysses mosaic in 1915. Internationally known since then thanks to this important

26 The mosaic has been severely destroyed, probably due to agricultural work carried out on the site in previous years. Thus, we hope in a more detailed analysis for the preparation of the Inventory of Roman Mosaics of Portugal underway within the scope of the RoGeMoPorTur project to be able to proceed with a detailed description not only of this mosaic but of other pavements present in this villa.

27 The frame of the square in the lower right corner seems to introduce the element "fish" in its decoration: the line of placement of the tesserae seems to confirm this interpretation

28 The frame of the square in the lower right corner seems to introduce the element "fish" in its decoration: the line of placement of the tesserae seems to confirm this interpretation

29 There are no parallel examples elsewhere in the Roman Empire: however, the research is not yet complete. 


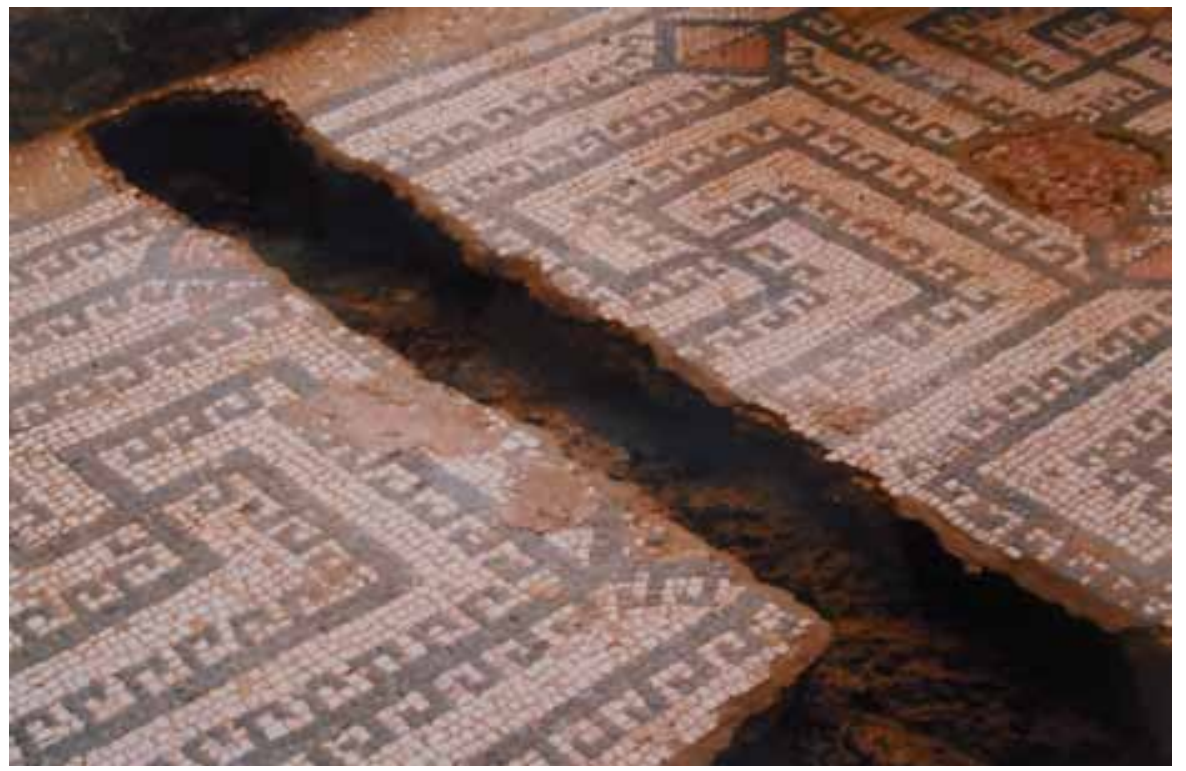

mosaic, discovered by Luís Chaves and raised during the campaigns of 1915/16, consolidated and deposited in the National Museum of Archaeology, where it still remains, this Roman villa has been the subject of several interventions of excavation, cleaning and preservation over the years.

An exhaustive analysis of the whole Bibliography related to Saint Vitória do Ameixial would exceed the established objectives. To do so, we shall mainly refer to the reports of the work carried out at that archaeological station in 1970 (Matos 1970) and 1986 (Carrilho - Dias 1986). However, we find it interesting to transcribe here a few insightful passages from the excavations report of 1970 .

"It can be considered that all or almost all of the resort and a large part of the urban villa have been lost due to the fact that new houses of the village have been constructed on top of the buildings of the zone, taking advantage of the discovered materials.

If we analyse the excavations of Luis Chaves we must recognize that they were very summary. He was asked to lift up the mosaic found in the place and to recognize the buildings so that mosaics or other valuable materials would not remain on the ground, and that is what he actually did "..." (Matos 1970: 2). The works of Chaves, on the other hand, concern only a small part, certainly the richest, but of little extent relative to the total perimeter of the great villa" (Matos 1970: 2). "In addition, the excavation of other areas of the station promises to be extremely profitable. The villa has an extension which, as we estimate by far, is ten times greater than the area already excavated encompassing the perimeter of the present village and surpassing it by much" (Matos 1970: 3).

It was during this 1970 excavation campaign that a number of mosaic pavements were discovered in an area not yet excavated, also partly destroyed by the machinery used in agriculture. Among them are two mosaics (peristyle and contiguous room) that, although presenting a different ordering and style of the floor in the villa of Herdade das Argamassas, introduces a variant of it (Fig. 13) in the elaboration of the composition.

In both pavements - and as far as we can verify - the swastika-meander is used as a structuring and, at the same time, decorative element. Basically executed in white tesserae for the background, and black for the geometric scheme, the 
mosaic setter introduced an element of movement, almost of discomfort when he took recourse to the line of hooks for the construction of the meander, aligned alternately in the inner part or on the outside of the baseline of the swastika, sometimes even on both sides.

The decorative syntax of this composition is enhanced by the introduction of a polychrome "separator" between each "swastika": a square on the tip outlined in black tesserae and filled by two triangles in opposite red and yellow colours, separated by a line of black tesserae placed on the vertex.

A first analysis of the common characteristics of the pavements of these three villae of the conventus pacensis, even with all the reservations related to both the poor conservation of the pavements and the different interpretation of the same motifs given in each of them, gives rise to the hypothesis of a possible identification of a regional mosaic workshop. The use of broad polychrome bands (yellow and black?) to delimit the composition, the preference for bi-chrome schemes, the introduction of stylistic elements such as the line of hooks, the use of peltce as unique motif in a surface composition, the use of the geometric system as a decoration element, can be considered elements of reference for the identification of a mosaic workshop. The analysis, when possible, of the remaining pavements of these villae and the surrounding villae may soon - so we hope - allow this identification.

\section{Bibliography - Kaynaklar}

Abraços 2005

Alarcão 1988

Alves 2002

Bairrão Oleiro 1992

Blanchard 1973

Boletim Municipal 1983

Borges 1986

Brazuna 2011

Carrilho - Dias 1986

Chaves 1956

Décor I

Duran Kremer 1999

Duran Kremer 2007

Duran Kremer 2016
M. F. Abraços, M.F.Para a Histótia da Conservação e Restauro do Mosaico Romano em Portugal, Unpublished PhD Thesis, University of Lisbon.

J. Alarcão,O Domínio Romano em Portugal, Paperback, Publicações Europa-América.

F. Alves, A Arquitectura e o mosaico romano de pavimento. Relações/Interacções), Dissertação de Mestrado em História da Arte, FCSH, Universidade Nova de Lisboa, Lisboa.

J. M. Bairrão Oleiro, Conimbriga. Casa dos Repuxos in Corpus dos Mosaicos Romanos de Portugal. Conventus Scallabitanus, I+II. Conímbriga.

M. Blanchard et al., "Répertoire graphique du décor géométrique dans la mosaïque antique", Bulletin de l'AIEMA, Mai 1973, 4 fascicule.

Boletim Municipal da Câmara Municipal de Beja, Fev./Março 1983,pag. 5.

M. F. Borges, Mosaicos Luso-Romanos em zona de influência de Olissipo e Collipo, Dissertação final de Mestrado em História de Arte, Faculdade de Ciências Sociais e Humanas, Universidade Nova de Lisboa, Lisboa.

S. Brazuna, “A Villa da Herdade das Argamassas - 1os resultados de um projecto em curso", 3 as Jornadas de Arqeuolopgia do Nordeste Alentejano, 228-240.

A. Carrilho - L. Dias, Santa Vitória do Ameixial. Relatório da campanha de limpeza de.

L. Chaves, Estudos lusitano-romanos. A "Villa" de Santa-Vitória do Ameixial” O Arqeuólog Português Vol. XXX (1938), Lisboa.

C. Balmelle - M. Blanchard Lemée - J. Christophe - J. P. Darmon - A. M. Guimier Sorbets - H. Lavagne R. Prudhomme - H. Stern, Le Décor Géométrique de la Mosaïque Romaine I, Paris, Picard Editeur, 1985.

M. J. Duran Kremer, Die Mosaïken der villa Cardilio (Torres Novas, Portugal). Ihre Einordnung in die musivische Landschaft der Hispania im allgemeinen und der Lusitania im besonderen, PhD Thesis, University of Trier.

M. J. Duran Kremer, “A villa romana da Abicada: uma introdução ao estudo da arquitectura e mosaicos”, Xelb 8, Vol.I, 204-222, Silves 2008.

M. J. Duran Kremer, "Inventário dos mosaicos romanos de Portugal: Cataloguização e análise de motivos geométricos”, Estudios sobre mosaicos antiguos y medievales, (Luz Neira editora). Roma, L'Erma de Bretschneider. 
Lancha - André 2000

Lancha - Oliveira 2013

Lopes 2003

Maia - Pereira 1972

Manière-Lévêque 2012

Matos 1970

Nunes Correia 2005

Nunes Ribeiro 1972

Pereira 2011

Raynaud 2009

Oliveira 2003

RHA 62008

Salies 1974

Silva Marques C. 2007

Teichner 2008

Vargas Vazquez 2016

Wrench 2008
J. Lancha - P. André, A villa romana de Torre de Palma in Corpus dos Mosaicos Romanos de Portugal. Conventus Pacensis 1. I+II. Lisboa.

J. Lancha - C. Oliveira, Algarve Este in Corpus dos Mosaicos Romanos de Portugal. Conventus Pacensis 2. Faro.

V. Lopes, Mértola na Antiguidade Tardia. A topografia histórica da cidade e do seu território na Antiguidade Tardia, CAM, Mértola.

M. Maia - M. A. Pereira, Relatório da Campanha de Escavações na vila romana de D. Pedro (Beja), DRCA.

A.-M. Manière-Lévêque, Corpus of the Mosaics of Turkey Vol.II, Xanthos, Part 2, The West Area, İstanbul, Ege Yayınları.

J. L. M. Matos, Santa Vitória do Ameixial. Relatório das escavações de 1970.

L. Nunes Correia, Decoração Vegetalista nos Mosaicos Portugueses, Edições Colibri, Lisboa.

F. Nunes Ribeiro, A Villa Romana de Pisões, pag.23, planta, Beja.

R. M. Pereira, Resultados dos Trabalhos Arqueológicos no Paço dos Vasconcelos (Maio de 2002 a Agosto de 2005), 849 -866, Actas do X Colóquio Internacional da Associação Internacional para o Estudo do Mosaico Antigo (AIEMA), Conimbriga.

M. Raynaud, Corpus of the Mosaics of Turkey, Vol. I, Xanthos, Part 1, The East Basilica, İstanbul, Ege Yayınları.

C. Oliveira, A villa romana de Rio Maior. Estudo de mosaicos, Trabalhos de Arqueologia 31, IPA, Lisboa.

Revista de História da Arte 6, Instituto de História da Arte, Faculdade de Ciências Socias e Humanas, Universidade Nova de Lisboa.

G. Salies, Untersuchungen zu den geometrischen Gliederungsschemata römischer Mosaïken, BJB 174, Köln.

M. B. Silva Marques C., Balneum da villa romana de Pisões. Análise Formal e Funcional, Unpublished Master's Thesis, FCSH, Universidade Nova de Lisboa.

F. Teichner, Entre tierra y mar, Zwischen Land und Meer, Studia Lusitana 3, MNAR.

S. Vargas Vazquez, "Diseños Geométricos en los Mosaicos del Conventus Astigitanus”, Archaeopress Roman Archaeology 13, Oxford.

L. N. C. Wrench, Decoração arquitectónica na ntiguidade Tardia, Corpus de escultura arquitectónica. Dissertação de Doutoramento em História da Arte da Antiguidade, Universidade Nova de Lisboa, Lisboa. 